\title{
TOURIST BEHAVIOUR OF JUNIOR HIGH SCHOOL STUDENTS OF THE SELECTED VOIVODESHIPS IN POLAND: THE SOCIO- DEMOGRAPHIC CONTEXT
}

\author{
Adrian P. LUbOWIECKI-VIKUK, ZBIGNIEW PODGÓRSKI \\ Institute of Geography, Kazimierz Wielki University, Bydgoszcz, Poland
}

Manuscript received: November 24, 2014

Revised version: January 28, 2016

\begin{abstract}
Lubowiecki-VIKUK A.P., PodGóRSKi. Z., 2016. Tourist behaviour of junior high school students of the selected voivodeships in Poland: the socio-demographic context. Quaestiones Geographicae 35(1), Bogucki Wydawnictwo Naukowe, Poznań, pp. 37-46, 2 tables.

AвSTRACT: Leisure-time behavior, including tourist activity among contemporary adolescents has raised great interest of scientists and the representatives of the tourism industry. Not only it is important to estimate the rate of tourism activity among adolescents, but also it is necessary to bear in mind the analysis of behavior shaped on account of their gender, place of residence, or level of education. An attempt to conduct such a study was made on the basis of survey data obtained within the group of 1,067 junior high school students of the selected voivodeships in Poland. The results obtained clearly indicate that almost $1 / 4$ of the students surveyed had not participated in tourist trips. This was particularly noticeable in the case of boys and students living in rural areas. It is important to take broader steps to stimulate young people's needs for tourism and sightseeing. First of all, from the family which is considered a social institution, it is expected to raise young generations in the spirit of tourism and active leisure. Family's contemporary problems: increasing poverty, or even its (partial) marginalization are commonly disregarded. A systemic approach (support for families by schools, social organizations, and government units) appears to be a successful solution, but it is a long-term and complex process.
\end{abstract}

KEYWORDS: junior high school students, adolescents, tourism activity, leisure-time behaviour, Poland

Corresponding author: Adrian P. Lubowiecki-Vikuk (lubowiecki@ukw.edu.pl)

\section{Introduction}

Tourist activity among various social backgrounds is an implementation of customized wishes of the individual, related to his or her realm of leisure and recreation, learning about tourist values of their own region, country or of the world and acquiring new experiences.

Social and economic development, respectively high income and having free time, have contributed to the dynamic development of the whole area of social activity, which is tourism. In general, tourism is understood as tourism comprises the activities of persons traveling to and staying in places outside their usual environment for not more than one consecutive year for leisure, business and other purposes. Tourism refers to all activities of visitors, including both 'tourists (over-night visitors)' and 'same-day visitors' (Recommendations... 1994: 5). It can also be defined as a multidirectional and interdisciplinary phenomenon (Przecławski 1993), which in terms of broader sense is the whole of the phenomena and relationships associated with 
human activities, involving temporary and voluntary change of residence and undertaken for a variety of purposes (Lubowiecki-Vikuk 2011).

Therefore there is no doubt that tourism is not only a sociocultural and space phenomenon but also an economic one. A consumer character of a lifestyle among residents of economically developed countries as well as developing countries favours the development of tourism industry, bringing specific benefits both for the national economy and for people who prefer or only accept the changing pattern of consumptions models. Simultaneously, it seems that the process of irrationality in developing rationalization of life which in tourism is called 'McDisneyization' (Ritzer 2012) acquires a new character. Maximizing efficiency, predictability and the influence of new technologies on tourist behaviour gives way to the idea of Contemporary Tourism, the so called 3E (Entertainment, Excitement, Education), (Lubowiecki-Vikuk, Paczyńska-Jędrycka 2010: 21) based on the desire for entertainment, emotions and education.

However, this idea is not mirrored in the tourist behaviour among all social groups. Adolescents constitute a category of quite unconventional consumers (Żelazna, GórskaWarsewicz 2013). On the one hand, they want all the benefits coming from $3 \mathrm{E}$ tourism - they are more inclined to take risks, seek new contacts, explore new cultures, they want to broaden their knowledge (Lubowiecki-Vikuk, Paczyńska-Jędrycka 2010, Richards 2011). On the other hand, they become consumers of typical products of 'McDisneyization' when visiting theme parks, participating in organized tours, spending their free time in shopping malls (adolescents regard them as a significant tourist attraction); they do not consume dishes of regional cuisine but only those they are familiar with from everyday life.

Parents or guardians have an indisputable influence on such behaviours (Niemczyk 2015). They expect that for the money given to their children, kids will see and experience as much as possible. As Ritzer (2012) says tourism has become a commodity that is advertised, issued on the market and sold just like any other goods. Can young people still experience the authenticity of visited sites? This question was answered by MacCannell (2013) without giving any illusions
- everyone falls victim to manipulations of the tourism industry.

The aim of this study is to estimate the rate of tourist activity among junior high school students in Poland and analyse tourist behaviour within the context of selected socio-demographic factors. It was assumed that tourist activity was demonstrated by at least one voluntary departure outside permanent residence during the past year, dictated by individual (non-earning) targets. A measure for this activity is the rate of tourist activity, i.e. the percentage ratio of people participating in tourism to all population studied.

It is universally recognized that factors most differentiating and at the same time shaping the level of tourist activity are, i.e. gender, age, educational level, level of income, health condition, family life cycle stage, place of residence and belonging to social and professional groups (Alejziak 2009, Alegre, Mateo, Pou 2010, Kattiyapornpong, Miller 2008, Lubowiecki-Vikuk 2011, Bernini, Cracolici 2015). It appears that gender is the factor that substantially affects the way adolescents manage their leisure time (Garton, Pratt 1991, Fitzgerald et al. 1995), as well as their personality (Trainor et al. 2010) and lifestyle (Lajunen et al. 2009). It must be acknowledged that behaviour of young people in their free time is determined by the stage of physical, mental and intellectual development. As a consequence, the results of observation of tourist behaviour among adolescents are also determined by the choice of educational stage, which features the surveyed (LubowieckiVikuk, Podgórski 2013) and current economic and institutional conditions (Żelazna, GórskaWarsewicz 2013).

\section{Literature review}

The age of learners studying in junior high schools indicates that they are in adolescence which is particularly causing a lot of controversies about the existing structure of the educational system. These young people undergo one of the most difficult stages of physical and intellectual development, which is complicated both for social coexistence as well as for themselves. The common features of adolescence are: mood swings (Teixeira et al. 2014), irritability, hyperactivity/laziness, etc. At this time, they tend to 
be impertinent, rebellious and occasionally aggressive (Steinberg, Morris 2001, Steinberg 2008). This is the time of growing tendencies to become independent from their parents (not economically), so that when making particular decisions adolescents are more susceptible to influence of peers. It seems that the school environment may fundamentally affect their behaviour, also in their leisure time.

During the lesson of physical education, junior high school students can choose from a selection of classes where, beside sports activities, agility and health activities and dancing, there is also active tourism (Ordinance of the Minister of National Education 2011). In this difficult period of adolescence, a young person has an opportunity to develop interests and help building a positive self-image - as a participant of physical activities of recreational, sporting or tourist character (Ordinance of the Minister of National Education 2012). It should be stressed that the most common initiators of school tourism are head teachers and PE teachers, and the organizers of school trips - travel agencies, other commercial entities and school (Żelazna, Górska-Warsewicz 2013: 48). Children and adolescents participate in school trips (year-round, one-day or three-day trips), take part in the socalled 'green/white schools' (1), and participate in elective trips, camps and the like (Żelazna, Górska-Warsewicz 2013: 41).

Leisure contributes to the overall development of young people and particularly influences the development of their identity (Freire 2013). A part of this leisure, in addition to recreational activities (Lubowiecki-Vikuk, Biernat 2015) is a tourist activity.

In contemporary society tourism has many important functions, i.e. social, economic, health, educational and political function (Gaworecki 2010). In Poland, since the 2nd half of the eighteenth century tourism (including sightseeing) has become an element of education of children and youth. Stanislaw Staszic (regarded as one of the precursors of Polish sightseeing and tourism) was an advocate of the thesis that by means of tourism one can teach patriotism and by tourism one can raise (Gaworecki 2010, LubowieckiVikuk 2011). Thus, it is difficult not to agree with the views of a prominent Polish sociologist of tourism Krzysztof Przecławski (1993, 2004), who believed that tourism is one of the most attractive forms of education and upbringing, especially if its institutional forms are defined by a carefully prepared programme of intentional education. The impact of educational value of tourism is the greater the sooner it starts; the earlier a young person is 'introduced' in tourism and 'taught' it is practicing (Przecławski 1973: 98). Via participation of children and adolescents in tourism there comes to establishing contacts, and integrating with nature. Young tourists learn how to cooperate in a group and how to be responsible for themselves and others. Within the family environment, by cause of tourist trips relationships among its members should also strengthen (Hilbrecht et al. 2008, Small 2008, Lehto et al. 2009). The educative function of tourism points to the fundamental role of pedagogics and particularly pedagogics of tourism. Its role is to interpret and implement crucial assumptions of the state's functioning, such as tourism, cultural and educational policies. This functionality is also reflected in undertaking practical educational activities which are directly implemented by institutions acting to promote tourism (universities, tourist organisations, etc.) as well as institutions and persons educating by tourism (schools, tourist associations, churches and religious associations, families) (Matuszyk 2003). The concept of tourism pedagogy is incorporated in the idea of lifelong learning. It involves acquisition of knowledge, improvement of intellect, shaping attitudes and the pursuit of knowledge for somebody's all life (Suprewicz 2005). Popularization of tourism, and in particular of the active one, should take the form of national and international tours, hikes and camps. These activities are an instrument of education of youth, and at the same time as stated by Wojciechowski et al. (2012) an attractive form of implementing educational and didactic tasks in contemporary schools.

Official and generally available statistics in the field of tourism activity generally applies to people over 15 years of age, and all analyses are conducted on the basis of research carried out in households. In the course of these studies, parents or guardians declare that in general the whole family including children participates in tourist activities. The results obtained prove that adolescents affect tourist behaviour of their 
parents (Pearce 2005). Simultaneously, these results allow to claim that the youngest part of the society is currently a very important segment of tourism market (Alejziak 2009).

The data gathered by the Institute of Tourism shows that during the period from 2006 to 2010 tourism activity rate among adolescents under 14 years of age was on average at the level of $42.8 \%$, while among adolescents aged 15-19 it was $65.6 \%$ (Eaciak 2011). In both age groups these were most often long-term domestic trips (31.0\% and $44.6 \%$ respectively), and national short-term trips (16.6\% and $29.6 \%$ respectively), followed by trips abroad (7.2\% and $19.2 \%)$. It is to be noted that in the participation rate in tourism among adolescents one shall include school trips organized during the school year and after-school trips, including holiday trips.

An important element of preparation of the tourist offer for young travellers is the purpose of their trips. As it is reported by Łaciak (2011) they travel for tourism and recreation, and/or for visiting relatives or friends. The purpose of the trip and its length fundamentally affect the accommodation and transport choice. When travelling, respondents were most frequently accommodated by their relatives or friends, B\&B's and other facilities of hotel nature (Łaciak 2011). Once these were school trips, the participants more often spent the night in the camp centres, holiday resorts, training and recreation resorts, creative work facilities, hostels, youth hostels, and also in hotels and other hotel facilities (Żelazna, Górska-Warsewicz 2013: 46). Their means of transportation was most often a coach (Łaciak 2011). For extracurricular trips, a means of transportation favoured by adolescents (72\% respectively) was a car (Łaciak 2011).

\section{Methodology}

The study included a representative (random-intentional) group of 1,067 lower secondary school students (the assumed error is 3\%; typical choice is $95 \%$ ) of the selected voivodeships in Poland (Masovia, Lodz Voivodeship, Greater Poland, Cuiavia and Pomerania, Warmia and Masuria).

The youth of junior high school - a social group formed by students of junior high schools.
In Poland, these are students aged 13-17. Once they have completed their primary school education (6 years), they are educated for the period of 3 years in junior high schools and subsequently continue their studies in upper secondary schools: high schools, technical or vocational schools. Junior high schools in the Polish educational system - as a second compulsory general education level - have been functioning since 1999. Before that year, education in the primary school lasted eight years. The sampling frame was CSO (Central Statistical Office) Local Data Bank collections, which showed that in Poland the number of pupils in lower secondary schools for children and adolescents (excluding special schools and for adults) was in the school year 2012/2013 over 1.1 million (1 133 709). Students' socio-cultural diversity along with lower capital intensity and greater availability and acceptance of schools authorities to do this kind of research contributed to the choice of this part of Poland region as an area of exploration. The study was conducted at the end of the summer season, i.e. September and early October 2013, the school year 2012/13 being under consideration.

In order to select the test group a two-stage draw system was applied. The first stage consisted of random selection among all lower secondary schools located of the selected voivodeships in Poland, covering two spatial layers: town, village. Then, in each school, one class of a given grade (first, second, third) was deliberately chosen, where research included all students present that day in geography class. A questionnaire survey was used as a research tool. A direct interview (standardized) was conducted by trained and supervised interviewers, according to the established plan. The author's own survey (modified after a pilot version) included questions on participation in tourist activities in the last year, i.e. their frequency (less than 3 times, 4-6 times, 7, and more), their duration (1-4 days, 5 or more) the purpose of leaving (holiday, educational, visiting relatives/friends, health, other) and holiday behaviours (staying at home, tourist trips with the family, visiting the family/relatives, staying at the camp). In addition to information on participation in tourist activities, interviewers also collected data on gender, grade (level of education) and place of residence of the respondents (Table 1 ). 
Table 1. Characteristics of the researched group of young people from lower secondary schools of the selected voivodeships in Poland $(n=1,067)$.

\begin{tabular}{|c|c|c|c|c|c|c|}
\hline \multirow{2}{*}{ Variables } & \multicolumn{2}{|c|}{ Boys } & \multicolumn{2}{|c|}{ Girls } & \multicolumn{2}{|c|}{ Total } \\
\hline & $\mathrm{n}$ & $\%$ & $\mathrm{n}$ & $\%$ & $\mathrm{n}$ & $\%$ \\
\hline \multicolumn{7}{|c|}{ Grade } \\
\hline I & 226 & 44.8 & 209 & 37.2 & 435 & 40.8 \\
\hline II & 130 & 25.7 & 160 & 28.5 & 290 & 27.2 \\
\hline III & 149 & 29.5 & 193 & 34.3 & 342 & 32.1 \\
\hline \multicolumn{7}{|c|}{ Place of residence } \\
\hline Town & 279 & 55.2 & 280 & 49.8 & 559 & 52.4 \\
\hline Country & 226 & 44.8 & 282 & 50.2 & 508 & 47.6 \\
\hline \multicolumn{7}{|c|}{ Voivodeships } \\
\hline Cuiavia and Pomerania & 355 & 70.3 & 369 & 65.7 & 724 & 67.9 \\
\hline Łódź Voivodeship & 38 & 7.5 & 45 & 8.0 & 83 & 7.8 \\
\hline Masovia & 32 & 6.3 & 49 & 8.7 & 81 & 7.6 \\
\hline Warmia and Masuria & 49 & 9.7 & 71 & 12.6 & 120 & 11.2 \\
\hline Greater Poland & 31 & 6.1 & 28 & 5.0 & 59 & 5.5 \\
\hline
\end{tabular}

The relationship between tourist behaviours during the school year and summer holidays and variables characterizing the structure of junior high school students (gender, level of education and place of residence) was determined using a $\mathrm{Chi}^{2}$ test. Analyses were made using the statistical package IBM SPSS Statistics version 21. In assessing the significance of the effects, the assumed level of significance was $\mathrm{p} \leq 0.05$.

\section{Results}

The rate of tourist activity of subjects questioned amounted to $76.5 \%$. The remaining respondents, i.e. $23.5 \%$ showed inactivity in this regard. The reasons for this kind of behaviour were mainly the lack of identified needs for tourism, the missing initiative to organize a tourist trip, lack of free time, lack of available financial resources, health issues and other.

The study detected no statistically significant relationships between tourist activity of respondents and their education level. This dependency appeared in the variables: gender and place of residence. The surveyed boys $(73.3 \%)$ undertook tourist activity relatively less than girls $(79.4 \%)$; $\left(\mathrm{Chi}^{2}=5.487 ; \mathrm{df}=1 ; \mathrm{p}=0.019\right)$, especially if they lived in rural areas $(68.6 \%$ vs. boys from the city $-77.1 \%$, girls from rural areas $-79.1 \%$, the girls from the city $-79.6 \%) ;\left(\mathrm{Chi}^{2}=10.499 ; \mathrm{df}=3\right.$; $\mathrm{p}=0.015$ ).

In the period studied, the junior high school students went somewhere for the purposes of tourism fewer than 3 times in the last year (43.1\%). A greater incidence of 4-6 times and 7 and more concerned $21.6 \%$ and $6.5 \%$ of respondents, respectively. Significant correlations between the frequency of tourist trips and socio-demographic characteristics of the subjects were not detected.

The obtained data show that a vast majority $(40.5 \%)$ of surveyed students - especially females $(63.9 \%$ vs. boys $-55.8 \%)$ and people living in the urban areas $(64.2 \%$ vs. rural areas - $55.6 \%)$ - participated in the long-term trips (5 days and more). However, slightly more frequently than the others, boys from urban areas chose longer trips $(65.9 \%$ girls from rural areas $-65.3 \%$, the girls from the city $-62.6 \%$, the boys from the village $-41.9 \%)$; $\left(\mathrm{Chi}^{2}=24.099 ; \mathrm{df}=3 ; \mathrm{p}=0.000\right)$. The remaining fraction $(26.7 \%)$, more often boys $(44.2 \%$ vs. $36.1 \%) ;\left(\mathrm{Chi}^{2}=4.888 ; \mathrm{df}=1 ; \mathrm{p}=0.027\right)$ and those living in rural areas (44.4\% vs. $35.8 \%)$; $\left(\mathrm{Chi}^{2}=5.437 ; \mathrm{df}=1 ; \mathrm{p}=0.020\right)$ chose shorter trips, lasting 4 days and below.

From among 1,067 surveyed students, 637 of them commented upon the purpose of trips undertaken by them. Yet the number of answers was 1,147 as it was possible to indicate in the questionnaire either one or more variants of answers. Students took advantage of this opportunity 331 times and some of them even several times. Part of the subjects $(16.8 \%)$ did not reveal tourism destination, nevertheless the most often indicated purpose of the undertaken trip was leisure $(59.7 \%)$, followed by visiting relatives and friends (25.9\%). For educational purposes (e.g. foreign language courses) went $14.5 \%$ of respondents, 
Table 2. Purposes of respondents tourist trips in socio-demographic context.

\begin{tabular}{|c|c|c|c|c|c|c|c|c|c|c|}
\hline \multirow{3}{*}{ Variables } & \multicolumn{10}{|c|}{ Purpose of tourist trips } \\
\hline & \multicolumn{2}{|c|}{ leisure } & \multicolumn{2}{|c|}{ education } & \multicolumn{2}{|c|}{$\begin{array}{l}\text { visiting rela- } \\
\text { tives and/or } \\
\text { friends }\end{array}$} & \multicolumn{2}{|c|}{ health } & \multicolumn{2}{|c|}{ other* } \\
\hline & $\mathrm{n}$ & $\%$ & $\mathrm{n}$ & $\%$ & $\mathrm{n}$ & $\%$ & $\mathrm{~N}$ & $\%$ & $\mathrm{n}$ & $\%$ \\
\hline \multicolumn{11}{|c|}{ Grade } \\
\hline $\mathrm{I}$ & 261 & 77.4 & 57 & 16.9 & 103 & 30.6 & 15 & 4.5 & 19 & 5.6 \\
\hline II & 171 & 76.7 & 38 & 17.0 & 92 & $41.3^{\mathrm{a}}$ & 10 & 4.5 & 6 & 2.7 \\
\hline III & 205 & 80.1 & 60 & 23.4 & 81 & 31.6 & 9 & 3.5 & 20 & $7.8^{\mathrm{b}}$ \\
\hline \multicolumn{11}{|c|}{ Gender } \\
\hline Girl & 346 & 77.6 & 96 & $21.5^{c}$ & 151 & 33.9 & 18 & 4.0 & 21 & 4.7 \\
\hline Boy & 291 & 78.6 & 59 & 15.9 & 125 & 33.8 & 16 & 4.3 & 24 & 6.5 \\
\hline \multicolumn{11}{|c|}{ Place of residence } \\
\hline Town & 343 & 78.3 & 83 & 18.9 & 155 & 35.4 & 14 & 3.2 & 30 & 6.8 \\
\hline Country & 294 & 77.8 & 72 & 19.0 & 121 & 32.0 & 20 & 5.3 & 15 & 4.0 \\
\hline \multicolumn{11}{|c|}{ Gender/place of residence } \\
\hline Girls from urban area & 177 & 79.4 & 47 & 21.1 & 77 & 34.5 & 4 & 1.8 & 10 & 4.5 \\
\hline Girls from rural area & 169 & 75.8 & 49 & 22.0 & 74 & 33.2 & 14 & 6.3 & 11 & 4.9 \\
\hline Boys from urban area & 166 & 77.2 & 36 & 16.7 & 78 & 36.3 & 10 & 4.7 & 20 & $9.3^{\mathrm{d}}$ \\
\hline Boys from rural area & 125 & 80.6 & 23 & 14.8 & 47 & 30.3 & 6 & 3.9 & 4 & 2.6 \\
\hline Total & 637 & 59.7 & 155 & 14.5 & 276 & 25.9 & 34 & 3.2 & 45 & 4.2 \\
\hline
\end{tabular}

* the purpose of sport, pilgrimage, cultural, agrotourism, shopping

a - grade II vs. grade III, grade I; ${ }^{\mathrm{b}}$ - grade III vs. grade I, grade II; ${ }^{\mathrm{c}}-$ girls vs. boys; ${ }^{\mathrm{d}}-$ boys from urban area vs. girls from rural area, girls from urban area, boys from rural area.

and these were more often girls $\left(\mathrm{Chi}^{2}=4.090\right.$; $\mathrm{df}=1 ; \mathrm{p}=0.043$ ). Trips for health purposes were chosen by $3.2 \%$, and for the purposes specified as "other" (including sports (2.5\%), pilgrimage, cultural, agro tourism, shopping) $-4.2 \%$ of respondents; these were more often boys residing in the city $\left(\mathrm{Chi}^{2}=9.080, \mathrm{df}=3, \mathrm{p}=0.028\right)$.

The frequency of selecting particular variants of responses to a question regarding the purpose of trips undertaken by students from grades I-III is markedly varied. Recreational and educational objectives were most frequently indicated by students of grade III $(80.1 \%$ and $23.4 \%$ respectively) while visiting relatives (friends) - students of grade II (41.3\%); Table 2. The health purpose was rarely mentioned, most often and to the same extent by the students of grades I and III (4.5\% each grade). On the other hand, a different purpose than those specified was given most frequently by junior high school students from grade III $(7.8 \%) ;\left(\mathrm{Chi}^{2}=6.017 ; \mathrm{df}=2 ; \mathrm{p}=0.049\right)$. What is interesting, their indications were almost three times more common than those of students from the first grade. Analysing the results (frequency of indicated variants of responses: the leisure purpose, visiting relatives (friends), the educational purpose, the health purpose, and other) it can be said that students are guided by nearly identical hierarchy of goals, regardless of which grade they are. Validity of the above conclusion is not undermined by the observation that students of grade II (to a greater extent than others) when making decisions about participating in tourist trips are guided by the intention of visiting relatives (friends) $-41.3 \%$ (average 34.5\%); $\left(\mathrm{Chi}^{2}=7.648\right.$; $\mathrm{df}=2, \mathrm{p}=0.022)$, and on the other hand, for students of grade III the educational purpose is clearly more important - $23.4 \%$ (average $19.1 \%$ ).

In order to determine the predominant forms of holiday behaviour among junior high school students of the central Polish voivodeships in the school year 2012/2013, a particular question was designed with four options of an answer. Replies were received from 1,066 students (out of 1,067 respondents) who specified their behaviour during the period of summer holidays by choosing answers (one or more variants) of a prepared closed set. A form of holiday behaviour most frequently indicated in the questionnaire form by junior high school students was staying at home $-39.5 \%$ (this was more often pointed out by those living in rural areas $-43.7 \%$ vs. $35.7 \%$; $\left.\mathrm{Chi}^{2}=7.189 ; \mathrm{df}=1 ; \mathrm{p}=0.007\right)$. Then, staying with family and relatives $-38.1 \%$ and a tourist trip 
with the family $-37.0 \%$ (especially undertaken by people living in the urban area $-44.1 \%$ vs. $29.1 \%$; $\mathrm{Chi}^{2}=25.515, \mathrm{df}=1, \mathrm{p}=0.000$, greatly among girls - $47.9 \%$ vs. boys from urban area $-40.3 \%$ girls from rural areas $-29.8 \%$, the boys from rural area $-28.3 \% ; \mathrm{Chi}^{2}=29.062 ; \mathrm{df}=3 ; \mathrm{p}=0.000$ ). Trips to the family and relatives were more frequent among students of grade II $(44.5 \%)$ vs. grade I $(37.2 \%)$ and grade III $(33.7 \%) ;\left(\mathrm{Chi}^{2}=8.193, \mathrm{df}=2\right.$, $\mathrm{p}=0.017)$, in particular females $(44.1 \%$ vs. $31.3 \%)$; $\left(\mathrm{Chi}^{2}=18.401, \mathrm{df}=1, \mathrm{p}=0.000\right)$ living in the city ( $46.8 \%$ vs. girls from rural area $-41.5 \%$ of urban boys $-31.7 \%$, the boys from rural area $-31.0 \%$; $\left.\mathrm{Chi}^{2}=20.097 ; \mathrm{df}=3 ; \mathrm{p}=0.000\right)$. Participation in the holiday camps was confirmed only by $-19.6 \%$ of respondents, more often by students of grade III $(24.3 \%)$ vs. grade I $(18.6 \%)$ and grade II $(15.5 \%)$; $\left(\mathrm{Chi}^{2}=8.193 ; \mathrm{df}=2 ; \mathrm{p}=0.017\right)$ and girls $(23.1 \%$ vs. $15.7 \%) ;\left(\mathrm{Chi}^{2}=9.347 ; \mathrm{df}=1 ; \mathrm{p}=0.002\right)$, especially those living in rural areas $(23.8 \%$ vs. girls from the cities $-22.5 \%$ boys of urban area $-18.7 \%$, boys from rural area - 11.9\%); $\left(\mathrm{Chi}^{2}=13,128\right.$; $\mathrm{df}=3 ; \mathrm{p}=0.004)$.

\section{Discussion}

It was found that the gender of the youth is the factor which basically determines the management of leisure time (Garton, Pratt 1991, Fitzgerald et al. 1995). Also, this study found that boys $(73.3 \%)$ undertook relatively fewer tourist activities than girls (79.4\%). However, if they did, this activity was definitely longer (5 days and more), and this was particularly true for those boys who lived in urban areas (65.9\%). In this way another important factor appeared, namely the place of permanent residence. Hence, tour operators and other entities should take into account the abovementioned considerations in order to adjust their leisure offers to the needs of youth and encourage boys and youth from rural areas to increase their rate of tourist activity.

Junior high school youth usually travel for recreational purposes and/or visiting relatives and friends. The stage of their development in the general life cycle suggests that the remaining purposes of tourist trips may come out with the increase in their age. Earlier studies demonstrated that university students through participation in tourism strive to achieve a number of purposes most frequently related to recreation, entertainment, and learning about the world (LubowieckiVikuk, Podgórski 2013). It should be expected that the growth of awareness of the needs of tourist nature among junior high school students will allow them to gain new experiences and emotions yet unknown to them (Llewellyn-Smith, McCabe 2008). Considering the results obtained, that argument can be justified. Tourist trips from educational motives undertaken by the youth are also regular; during these trips young people have an opportunity to learn how to interchange within a particular social group, which is different from their family.

On the basis of author's own studies it was found that adolescents often spend their holiday time at home, particularly those who live in rural areas. The reasons for this can be explained by the fact that during the summer, young people are frequently involved either in work on a farm (in the field) or in some other duties resulting from living on a farm. This fact does not raise major objections in a social environment. Bearing in mind the purposes of tourist trips and particularly those identified as "other", where agro tourism was listed, one should agree that recreation of the youth from rural areas and their attitude towards nature continue to be only partially recognized (King, Church 2013).

However, the vast majority of respondents during the holiday season left for the family or relatives, or went on a tourist trip with their family. It is also emphasized that adolescents traveling with their parents draw even more satisfaction from such kind of recreation than their parents (Nickerson, Jurowski 2001). This case was proven particularly characteristic for girls residing in the city. What is more, it clearly underlines the fact that adolescents actually have a need for contact, conversation and attention from parents, who normally are absorbed in work and other numerous responsibilities. At adolescence, the important role of parents is commonly emphasized. Not only are parents obliged to raise and educate their children, but also they need to protect them from problematic behaviours manifested by others (Piko, Vazsonyi 2004). Mahoney and Stattin (2000) pointed out that the youth participation in highly organized forms of recreation is associated with a low level of antisocial behaviours. Owing to lack of time and/or money, 
some parents of the students questioned (19.6\%) paid for the holiday of their children at summer camps, in which generally the oldest respondents (grade III), including girls living in rural areas participated.

Young people have become one of the segments of the tourist market (Alejziak 2009, Lubowiecki-Vikuk, Paczyńska-Jędrycka 2010, Richards 2011, Żelazna, Górska-Warsewicz 2013, Poria, Timothy 2014), for which adequate tourist products are proposed. Today, these products are based on an analysis of the development of social media and information and communication technologies used among young consumers (Bizirgianni, Dionysopoulou 2013). The most common tourist products for the youth are packages of services in the form of camps.

Domestic and foreign market offer theme summer camps': a dance camp - with various dance styles, including Hip-Hop (Xie, Osumareb, Ibrahim 2007), a camp 'on horseback', sailing camps, sports camps, survival camps , 'treasure hunt' camps, etc., along with language camps (mainly English, German, Italian, Spanish language). A rich and diversified program of summer and winter camps contains many suggestions for active recreation. Tour operators encourage adolescents to travel to both Polish and foreign seaside and mountain resorts (in particular, countries of the Mediterranean basin, Germany, the Czech Republic and Slovakia).

As not all parents or guardians can afford (due to lack of time and/or limited funds) a joint family tourist trip - so the popularity of camps in Poland is not decreasing (Lubowiecki-Vikuk, Paczyńska-Jędrycka 2010). This is actually an optimistic sign, as young people have a chance to participate not only in active forms of recreation - which is a prerequisite for staying healthy - but also in sightseeing, mainly in the form of going for trips, learning about their native country, gathering and popularizing all information about the country and yet acting for preserving and multiplying natural and cultural resources (Gaworecki 2010). The research conducted by Lubowiecki-Vikuk and Paczyńska-Jędrycka (2010: 59-60) clearly shows that adolescents when at summer camps not only swim with great willingness or participate in various games and activities, but also take part in numerous tours by coach.

\section{Conclusions}

The results based on author's own research indicate that the rate of tourist activity among junior high school students in Poland $(76.5 \%)$ is on average greater by more than 20 percentage points as compared to previous scientific reports (Eaciak 2011), and yet it is lower by approximately 13 percentage points in relation to university students (Lubowiecki-Vikuk, Podgórski 2013). The aforementioned tourist activity in the form of specific travel behaviours is developed under the influence of socio-demographic factors. Gender and place of residence of the respondents had far more likely an impact on such behaviours rather than the level of education.

The authors need to emphasize a very distinctive feature of Polish junior high school students. They are in puberty, which often results in mood swings, irritability, hyperactivity, laziness, etc. It is a period of time in which young people make various decisions, often difficult to understand or even to accept by adults. The way adolescents participate in tourism, especially during summer holidays reveals a number of problems afflicting Polish society (e.g. the impoverishment of large social groups, marginalization of the population). There is an urgent need for a systematic approach in the promotion and support of youth free time activity.

Nonetheless, leisure time behaviours and particularly tourist behaviours of young people appear to be predictable. On the basis of individual as well as other authors' research, the rate of tourist activity, the factors upon which it depends or whom it is influenced by have been established. Parents are fundamentally the initiators, oftentimes creators and patrons of the recreation and tourist activity of their children.

\section{Limitations and future research}

This analysis is subject to certain restrictions. Questionnaire surveys were conducted on the basis of declarations of junior high school students, which - despite a thorough clarification terminology used - could have led to over - or underestimation of tourist activity. Therefore, it is essential to carry out similar studies also among the caregivers of children. One of the distinctive 
characteristics of Polish youth group is its diversification resulting from the spatially variable socio-economic and cultural backgrounds. For this reason, the study is restricted to the selected voivodeships in Poland. The selected area includes (among others) lands with the lowest (Masovia voivodeships) and the highest (Warmia and Masuria, Cuiavia and Pomerania voivodeships) unemployment rate in Poland which is strongly diversified in terms of income per capita in the family - the highest level presented by residents of Mazovia Voivodeships. Simultaneously, the central area is quite homogenic in cultural, ethnical and religious terms. Furthermore, it was considered important that the creation of tourist behaviour pattern of this market segment based solely on socio-demographic factors is not entirely comprehensive and justified. Not only quantitative research, but also studies of a qualitative nature are emphasized in this case.

The study requires cyclicality and interdisciplinary scientific approach. It is also essential for social theorists to cooperate (especially theorists of pedagogy, sociology, psychology, and economics) as well as theorists of natural sciences, physical education and health sciences.

Research works which problems fall within the scope of studying tourist activity, especially among children and adolescents are not considered numerous (Gough 2008, Lubowiecki-Vikuk, Podgórski 2013). In the context of scientific argument, it is advisable to strive to identify tourist behaviour of the above social group, and consequently to create a model of its behaviour in leisure time, where tourism occupies a unique place. On one hand, it will allow to identify the level of participation of young people in tourism, while on the other hand it will provide an empirical image of the youngest consumer of tourism services useful for various economic entities. As a consequence, the obtained result will also be a contribution to broader studies that would take into account the results of in-depth observation of youth and be interpreted following megatrends of civilization reflected in tourism.

\section{Notes}

(1) Children and adolescents can at least once every school year leave their habitual residence for the so-called 'green school' (in the spring season) or 'white school' (during the winter season).
At that time, they learn to cooperate socially outside the school environment, they also meet new colleagues. These trips are considered an alternative to formal education, mass and uniform consumer reception of the surrounding reality (Żelazna, Górska-Warsewicz 2013: 38).

\section{Acknowledgments}

Thanks to Magdalena Nocny, Artur Gębka and Andrzej Podgórski, the final manuscript is infinitely better than anything that we could have produced without their support.

\section{References}

Alegre J., Mateo S., Pou L., 2010. An analysis of households' appraisal of their budget constraints for potential participation in tourism. Tourism Management 31: 45-56.

Alejziak W., 2009. Determinanty i zróżnicowanie społeczne aktywności turystycznej (Determinants and social diversity of tourist activity). AWF, Kraków.

Bernini C., Cracolici M.F., 2015. Demographic change, tourism expenditure and life cycle behaviour. Tourism Management 47: 191-205. DOI 10.1016/j.tourman.2014.09.016

Bizirgianni I., Dionysopoulou P., 2013. The Influence of Tourist Trends of Youth Tourism through Social Media (SM) \& Information and Communication Technologies (ICTs). Procedia - Social and Behavioral Sciences 73: 652-660. DOI 10.1016/j.sbspro.2013.02.102.

Fitzgerald M., Joseph A.P., Hayes M., O'Regan M., 1995. Leisure activities of adolescent schoolchildren. Journal of Adolescence 18(3): 349-358. DOI 10.1006/jado.1995.1024.

Freire T., 2013. Leisure Experience and Positive Identity Development in Adolescents. In: Freire T. (ed.), Positive Leisure Science From Subjective Experience to Social Contexts. Springer, Netherlands: 61-79. DOI 10.1007/978-94-0075058-6 4.

Garton A.F., Pratt C. 1991. Leisure activities of adolescent school students: predictors of participation and interest. Journal of Adolescence 14(3): 305-321. DOI 10.1016/01401971(91)90023-K.

Gaworecki W.W., 2010. Turystyka (Tourism). 6th ed., PWE, Warszawa.

Gough K.V., 2008. Guest Editorial Introduction: Nordic Geographies of Children and Youth. Geografiska Annaler: Series B, Human Geography 90: 217-226. DOI 10.1111/j.14680467.2008.288.x.

Hilbrecht M., Shaw S.M., Delamere F.M., Havitz M.E., 2008. Experiences, perspectives, and meanings of family vacations for children. Leisure/Loisir 32(2): 541-571.

Kattiyapornpong U., Miller K.E., 2008. A practitioner's report on the interactive effects of socio-demographic barriers to travel. Journal of Vacation Marketing 14(4): 357-371.

King K., Church A., 2013. 'We don't enjoy nature like that': Youth identity and lifestyle in the countryside. Journal of Rural Studies 31: 67-76. DOI 10.1016/j. jrurstud.2013.02.004.

Lajunen H-R., Keski-Rahkonen A., Pulkkinen L., Rose R.J., Rissanen A., Kaprio J., 2009. Leisure activity patterns and 
their associations with overweight: A prospective study among adolescents. Journal of Adolescence 32(5): 10891103. DOI 10.1016/j.adolescence.2009.03.006.

Lehto X.Y., Choi S., Lin Y-Ch., MacDermid S.M., 2009. Vacation and family functioning. Annals of Tourism Research 36(3): 459-479. DOI 10.1016/j.annals.2009.04.003

Llewellyn-Smith C., McCabe V.S., 2008. What is the attraction for exchange students: the host destination or host university? Empirical evidence from a study of an Australian university. International Journal of Tourism Research 10(6): 593-607.

Lubowiecki-Vikuk A.P., 2011. Determinanty aktywności rekreacyjno-turystycznej osób samotnych w Wielkopolsce (Determinants of recreational and tourism activity among single men and women from the Wielkopolska Province). AWF, Poznań.

Lubowiecki-Vikuk A.P., Biernat E., 2015. Zorganizowane i niezorganizowane formy aktywności fizycznej młodzieży gimnazjalnej w czasie wolnym na tle czynników osobniczych i społeczno-środowiskowych (Organized and unorganized forms of physical activity in leisure time among junior high school students in relation to individual and socio-environmental factors). Problemy Higieny i Epidemiologii 96(2): 448-457.

Lubowiecki-Vikuk A.P., Paczyńska-Jędrycka M., 2010. Wspótczesne tendencje w rozwoju form rekreacyjnych i turystycznych (Contemporary trends in the development of recreational and tourist forms). Bogucki Wydawnictwo Naukowe, Poznań.

Lubowiecki-Vikuk A.P., Podgórski Z., 2013. Zachowania i preferencje turystyczne młodzieży akademickiej (Tourist behavior and preferences the academic youth). In: Pawlusiński R. (ed.), Wspótczesne uwarunkowania i problemy rozwoju turystyki. IGiGP, Uniwersytet Jagielloński, Kraków: 149-158.

Łaciak J., 2011. Aktywność turystyczna dzieci i młodzieży w 2010 roku (Tourist activity of children and adolescents in 2010). Instytut Turystyki, Warszawa.

MacCannell D., 2013. The Tourist: A New Theory of the Leisure Class. University of California Press.

Mahoney J.L., Stattin H., 2000. Leisure activities and adolescent antisocial behavior: The role of structure and social context. Journal of Adolescence 23(2): 113-127. DOI 10.1006/jado.2000.0302.

Matuszyk A., 2003. Pedagogika turystyki jako stosowana aksjologia podróży (Pedagogy of tourism as applied axiology travel). In: Winiarski R. (ed.), Nauki o turystyce. AWF, Kraków: 127-142.

Nickerson N.P., Jurowski C., 2001. The influence of children on vacation travel patterns. Journal of Vacation Marketing 7(1): 19-30. DOI 10.1177/135676670100700102

Niemczyk A. 2015. Family decisions on the tourist market. Economics and Sociology 8(3): 272-283. DOI: 10.14254/2071-789X.2015/8-3/19

Pearce Ph.L., 2005. Tourist Behaviour. Themes and Conceptual Schemes. Clevedon, Buffalo, Toronto.

Piko B.F., Vazsonyi A.T., 2004. Leisure activities and problem behaviours among Hungarian youth. Journal of Adolescence 27(6): 717-730. DOI 10.1016/j.adolescence.2004.02.004.

Poria Y., Timothy D.J., 2014. Where are the children in tourism research? Annals of Tourism Research 47: 93-95. DOI 10.1016/j.annals.2014.03.002
Przecławski K., 1973. Turystyka a wychowanie (Tourism vs. education). Instytut Wydawniczy Nasza Księgarnia, Warszawa.

Przecławski K., 1993. Tourism as the subject of interdisciplinary research. In: Pearce D.G., Butler R.W. (eds), Tourism research: Critiques and Challenges. Routledge, London, New York: 9-19.

Przecławski K., 2004. Człowiek a turystyka: zarys socjologii turystyki (Man and tourism: an overview of the sociology of tourism). FHU Albis, Kraków.

Recommendations on Tourism Statistics, 1994. United Nations and World Tourism Organization, New York.

Richards G., 2011. The economic impact of youth travel. In: The Power of Youth Travel. WYSE Travel Confederation/ UNWTO.

Ritzer G., 2012. The McDonaldization of Society: 20th Anniversary Edition. 7th ed. SAGE Publications, Inc.

Rozporządzenie Ministra Edukacji Narodowej z dnia 27 sierpnia 2012 r. w sprawie podstawy programowej wychowania przedszkolnego i kształcenia ogólnego w poszczególnych typach szkół (Ordinance of the Minister of National Education dated 27 August 2012 on the core curriculum of preschool and general education in particular types of schools) (Dz.U. poz. 977, z późn. zm.).

Rozporządzenie Ministra Edukacji Narodowej z dnia 9 sierpnia 2011 r. w sprawie dopuszczalnych form realizacji obowiązkowych zajęć wychowania fizycznego (Ordinance of the Minister of National Education dated 9 August 2011 on the acceptable forms of implementation of compulsory physical education classes) (Dz.U. nr 175, poz. 1042).

Small J., 2008. The absence of childhood in tourism studies. Annals of Tourism Research 35(3): 772-789. DOI 10.1016/j. annals.2008.06.002

Steinberg L., 2008. Adolescence. 8th ed. McGraw-Hill, New York.

Steinberg L., Morris A.S., 2001. Adolescent Development. Annual Review of Psychology 52: 83-110.

Suprewicz J., 2005. Socjologia turystyki (Sociology of tourism). Wydawnictwo Akademickie Wyższej Szkoły SpołecznoPrzyrodniczej w Lublinie, Lublin.

Teixeira A., Silva E., Tavares D., Freire T., 2014. Portuguese validation of the Emotion Regulation Questionnaire for Children and Adolescents (ERQ-CA): relations with self-esteem and life satisfaction. Child Indicators Research 8. DOI 10.1007/s12187-014-9266-2

Trainor S., Delfabbro P., Anderson S., Winefield A., 2010. Leisure activities and adolescent psychological well-being. Journal of Adolescence 33(1): 173-186. DOI 10.1016/j.adolescence.2009.03.013.

Wojciechowski K.H., Bochenek M., Kędra P., Rafalska B., 2012. The influence of a specific tourist and sightseeing program on region related knowledge. Polish Journal of Sport and Tourism 19(3): 202-207.

Xie P.F., Osumareb H., Ibrahim A., 2007. Gazing the hood: Hip-Hop as tourism attraction. Tourism Management 28(2): 452-460. DOI 10.1016/j.tourman.2006.03.009

Żelazna K., Górska-Warsewicz H., 2013. Zachowania turystyczne młodzieży (Tourist Behaviour of Youth). Problemy Turystyki i Rekreacji 2: 36-51. 